\title{
CYTOGENETIC ABNORMALITIES IN SEED PROGENIES OF Pinus pallasiana D. DON STANDS FROM TECHNOGENIC POLLUTED LANDS IN THE STEPPE OF UKRAINE
}

\author{
IVAN KORSHIKOV ${ }^{1,3}$, YULIA BELONOZHKO², HELENA LAPTEVA $^{3}$ \\ ${ }^{1}$ Donetsk Botanical Garden of the National Academy of Sciences of Ukraine, 50 Marshaka Str., 50089 Krivoy Rog, \\ Ukraine; e-mail: ivivkor@gmail.com \\ ${ }^{2}$ Institute of Food Biotechnology and Genomics of National Academy of Sciences of Ukraine, Osipovsky Str., 2-a, \\ Kiev, Ukraine; e-mail: belonojkoua@gmail.com \\ ${ }^{3}$ Krivoy Rog Botanical Garden of the National Academy of Sciences of Ukraine, 50 Marshaka Str., 50089 Krivoy Rog, \\ Ukraine; e-mail: botgard@ukpost.ua
}

\begin{abstract}
Korshikov I., Belonozhko Y., Lapteva H.: Cytogenetic abnormalities in seed progenies of Pinus pallasiana D. Don stands from technogenic polluted lands in the steppe of Ukraine. Ekologia (Bratislava), Vol. 38, No. 2, p. 117-125, 2019.

In this study, we compare the pathological mitosis rates, chromosomal abnormalities and nucleolar organizer activity in Pinus pallasiana D. Don seedlings from natural population in the Crimean Mountains and from the urban plantations in the steppe of Ukraine. On the stages of anaphase and telophase of mitosis, such chromosomal abnormalities as bridges were most often found in the seeds of plantations exposed to air pollutants, whereas lead and agglutination of chromosomes were found in seeds from iron ore dump stands. Our studies have shown that $P$. pallasiana can be used for genotoxic monitoring of technogenic polluted lands.
\end{abstract}

Key words: Pinus pallasiana, cytogenetic abnormalities, nucleolar activity, technogenic lands, air and soil pollution.

\section{Introduction}

Analysis of the range and frequency of cytogenetic abnormalities in the mitotic division of living organism cells is used to assess the genotoxic effects of the technogenic environments (Akinboro et al., 2011; Wang et al., 2014; Pekol et al., 2016; Koca et al., 2016). Such investigations on natural objects are relevant in industrial regions and centres in the steppe zone of Ukraine, occupying $40 \%$ of its total area. Actually, more than 169 million $\mathrm{m}^{3}$ of industrial waste is annually produced in the course of production process in Krivoy Rog region. This small region is specializes in iron ore production. The area of quarries, mines, concentrating mills and sludge dumps located there is 35 thousand ha, including over 7 thousand ha of iron ore dumps. In addition to iron, these dumps contain precious and rare earth metals. Environmental man-induced migration of heavy metals in Krivoy Rog causes the so-called 'metal press' on the human body and other elements of the biota, acting as a destabilization factor of their living environments (Lysyi et al., 2007). 
Coke and steel plants, coal-fired thermal power plants, mining dumps produce $91 \%$ of total emissions in the industrialized Donetsk region. The largest percentage of industrial emissions falls to the share of Mariupol (20.5\%) and Donetsk (9.1\%). Carbon monoxide (31.3\%), methane (23.2\%), sulphur dioxide (24.3\%), nitrogen oxides (6.6\%) dominate among the air pollutants. In addition, the atmosphere of Mariupol and Donetsk is contaminated by dust, phenol and formaldehyde. There are areas with high soil contamination with mercury (2.6 to $2.8 \mathrm{mg} / \mathrm{kg}$ ), lead (145.4 mg/kg), manganese (5438 mg/kg), and chromium (1012 mg/kg) in Mariupol. A considerable amount of dust emitted to the atmosphere falls to the share of Novoamvrosievka cement plant ( $42.8 \%$ of total dust emissions in the Donetsk region). Basic components of the cement dust are calcium oxides (up to 60\%), silica dioxides (up to 20\%) and oxides of metals (up to 20\%) (Kumar et al., 2008; Mishra, Siddiqui, 2014; Genisel et al., 2015). There are cancerogenic and mutagenic substances in the emissions of industrial enterprises in Donbass and Krivbass, for example, benzapyrene, which is not controlled by any sanitary and epidemiological service. In addition, rare earth metals, extracted from the soil and then dumped as a waste, contribute to the background radiation (Nouri, Haddioui, 2016). Qualitative and quantitative heterogeneity of physical and chemical agents in polluted and degraded lands makes it possible to evaluate specific genotoxicity of these agents. Conifers are often subjected to such a research (Geras'kin et al., 2005; Kalashnik, 2008; Korshikov et al., 2012; Kalashnik, Yasovieva, 2012). Pinus pallasiana D. Don, rather widespread and successfully growing in industrial regions of Ukrainian steppe, including Krivoy Rog iron ore dumps, is applicable in cytological and physiological studies (Bessonova, Grytsay, 2018). Dominating air pollution in Donetsk region or soil pollution (iron ore dumps) in Krivoy Rog region is likely to ambivalently influence both the frequency of cytogenetic aberrations and their range in living organisms.

The aim of our study is to analyse cytogenetic abnormalities in P. pallasiana under conditions of different types of industrial and edaphic environmental pollution to determine their specific effects.

\section{Material and methods}

P. pallasiana seedlings of seeds sampled from four urban plantings in the Ukrainian steppe were the objects of our research. The first plantation (Mariupol) is exposed predominantly to the emissions of metallurgical industry; the second one (Novoamvrosievka) is within a kilometre from the Europe's biggest cement plant, the third plantation (Donetsk) is located along the heavily trafficked road; the fourth one (Krivoy Rog) is found on the Pervomaysky iron ore dump of the Severny (Northern) Mining and Concentrating Mill (background air pollution). Age of plants in these plantations ranged from 25 to 40 years. Seeds were collected separately from 25 to 30 trees in plantations. As control, we used seeds from natural population in the Crimean Mountains (near the settlement of Nikita), collected from 40 trees aged 80 to 100 . We studied seed progenies for cytogenetic effects, such as the range and rate of pathological mitosis, chromosomal abnormalities, and nucleolar activity.

Analyses were performed on temporary preparations of meristematic tissues of seedling roots (seeds sampled from each tree). The seeds were germinated in Petri dishes on wet filter paper in an oven at the temperature of 23 to $25^{\circ} \mathrm{C}$. Roots were fixed in acetic ethanol (1:3) and then stained with aceto-orcein. We used $50 \%$ solution of silver nitrate for staining of the nucleoli (Hozak et al., 1992; Treré, 1994). After staining, we rinsed the roots and prepared squashed preparations by the standard method (Pausheva, 1980). Micropreparation analysis was performed using a Carl Zeiss Primo star microscope (40x10 zoom) and Axio Vision Rel. 4.7 software. To carry out the analysis of mitosis, we counted all the cells at the stages of anaphase and telophase registering the percentage of cells with abnormalities. We classified mitotic pathologies and chromosomal abnormalities according to Bochkov et al. (1972) and 
Glinska (2007), (Bochkov et al., 1972; Glinska et al., 2007). The number of nucleoli was counted in 1000 cells from each sample. The functional state of nucleolar organizer was evaluated according to nucleoli number, their sizes and the value of nucleus-nucleolus ratio. Conditional areas of nuclei and nucleoli were determined by their projections and the ratios of these areas were calculated.

\section{Results and discussion}

Lagging and lead of some chromosomes and less frequently multipolar mitosis were the major types of pathological mitosis found in seedling roots of $P$. pallasiana seeds at the stages of anaphase and telophase. Only lagging and lead were detected in plant seeds from control Crimean population and Donetsk plantation whereas a full range of mitotic abnormalities was observed in seeds from Mariupol and Krivoy Rog plantations (Table 1). Multipolarity is considered to be a specific response to heavy metal effects (Geras'kin et al., 2005; Belousov et al., 2012), present in excess among pollutants of these cities' environments. It should be noted that the progeny of $P$. pallasiana growing in an iron ore dump has the highest frequency of occurrence of all the three mitosis pathologies, namely lead $(2.23 \%)$, lagging $(0.49 \%)$, multipolarity $(0.02 \%)$. The frequency of mitosis abnormalities in seed root cells was by times higher in technogenic ecotopes: by 30.4 times (in Krivoy Rog), by 4.4 times (Donetsk), by 3.1 (Mariupol) and by 2.1 times (Novoamvrosievska) than in the progeny of a Crimean natural population. Evidently, this fact is indicative of the specific effects of different qualitative types of pollution.

We have revealed four types of chromosomal abnormalities: bridges, chromosome fragmentation, ring chromosome and agglutination in seed root cells of the study plant samples. Only two types of abnormalities were found in the progeny of Crimean population, whereas all the four were present in the plants of each plantation (Table 1).

Such abnormalities as bridges were most often represented in the progenies of population and three plantations exposed mostly to air pollutants $(0.03 \%$ in a population, $0.61 \%$ in Novoamvrosievka, $0.92 \%$ in Donetsk and $1.25 \%$ in Mariupol plantations). Along with a high percentage of bridges (1.27\%), such a type of chromosomal abnormalities as agglutination $(1.52 \%)$ was also predominant in the seed progeny of $P$. pallasiana plants growing in an iron ore dump. An increased frequency of such a rare abnormality as ring chromosome $(0.1 \%)$ was also a specific feature of this plantation's progeny. This chromosomal abnormality was either absent or by order lower in other stands. Chromosomal abnormalities were more common than pathological mitosis in plant progenies from three plantations, exposed to the man-induced emissions. For example, the chromosomal abnormalities were, by many times, more frequent than the pathological mitosis in Novoamvrosievska, Donetsk and Mariupol plantations (by 3.4, 2.4 and 4.9 times, respectively). Just the converse effect was observed in the plant progeny from natural population, where pathological mitosis was 2.3 times more commonly present. We observed no significant differences in the frequencies of pathological mitosis and chromosomal abnormalities in the plant progenies from iron ore dump plantation. In general, these cytogenetic pathologies were much more common in seed progenies of P. pallasiana plantations from technogenic polluted lands (by 6.5 times in Novoamvrosievska, by 10.4 times in Donetsk, by 12.6 times in Mariupol and by 43.4 times in Krivoy Rog plantations), than in the plant progenies of natural population. It is obvious that cytogenetic abnormalities occurred by 3.4-6.7 times more often in plants from an iron-ore dump, than 


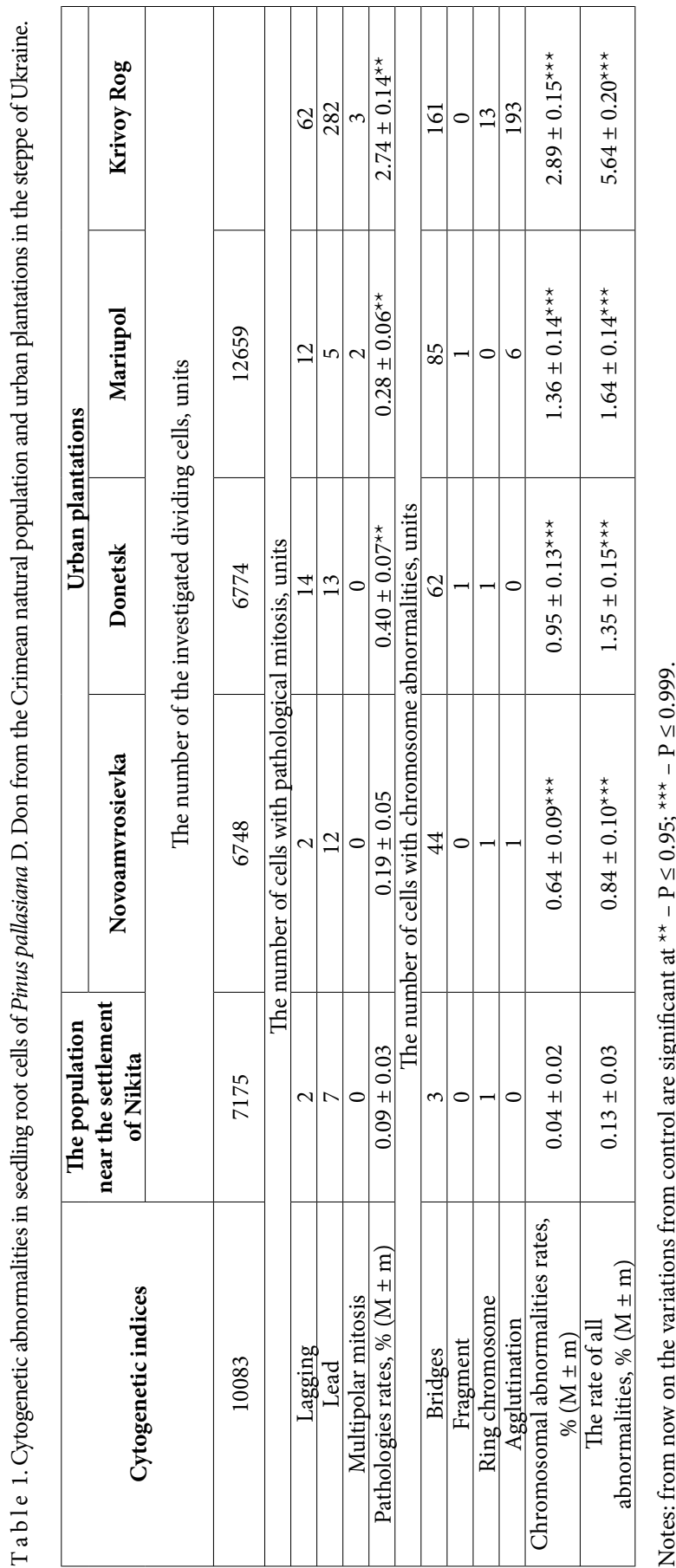

in three other stands of industrial cities. This fact can be accounted for by the high pollution of the overburden dump rock by heavy metals, including rare earth ones, contributing to the high background radiation and accumulated by plants. Laboratory studies on the root apical meristem cells of onion (Allium cepa L.) seedlings have shown that the salts of cadmium, lead, nickel, aluminium, copper and zinc (concentrations of $10^{-6}$ to $10^{-3} \mathrm{M}$ ) caused various cytogenetic damage: fragmentation, stickiness and lagging of chromosomes, chromosome bridges, multipolar anaphases, K-mitoses and chromosome condensation abnormality (Kalaev, Karpova, 2003; Stevens et al., 2007; Wang et al., 2014). The increased rates of these disorders were detected in plant seedlings of four coniferous species from technogenic polluted areas of the Southern Urals. Scots pine (Pinus sylvestris L.) was the most highly sensitive among these species, the frequency of mitotic abnormalities in its seeds ranging from 1.40 to $19.88 \%$ in different ecotopes. In seed progenies of three other species, this range was as follows: 2.6 to $6.8 \%$ in $\mathrm{Pi}$ cea obovata Ledeb., 4.34 to $6.8 \%$ in Abies sibirica, 4.0 to 
8.6\% in Larix sucaszewii Dyl. (Kalashnik, 2008). The number of chromosomal anomalies detected at the stage of metaphase was 7.5 to 16.05 times higher in seedling roots of these four conifer species' seeds from the polluted lands of the Southern Urals, than in the progenies of control stands. In addition, four to five types of anomalies are found in the seeds of conifers under polluted conditions, whereas no more than one to three types are typically found in plants under background conditions (Dovgalyuk et al., 2001; Kalashnik, 2008; Belousov et al., 2017).

An increased frequency of pathological mitoses (5.7\%) in the seed progeny of Betula pendula in the Voronezh region is associated with air pollution with benzapyrene. Basing on comparisons of Pinus sylvestris seed progenies in the Voronezh regional nature reserves and technogenic polluted areas inclusive of the site within one kilometre from Novovoronezhskaya Nuclear Power Plant, the authors consider mitosis pathologies below 5\% in the seedling roots to be the norm for assessing seed quality and using this species as a test object for cytogenetic monitoring of the environments (Butorina et al., 2002).

Cytogenetic abnormalities in the higher plants' cells induced by mutagens depend not only on their chemical composition (Liu et al., 1993; Butorina et al., 2001; Shkarupa et al., 2010), but also on their optical stereoisomerism. For example, S (+) stereoisomers of nitrosoalkylurea show twice higher activity in relation to seedling chromosomes of winter soft wheat (Triticum aestivum L.), than (R-) stereoisomers. The frequency of typical chromosome aberrations in seedling anaphase cells of T. aestivum depends on mutagen, its applied concentration, the variety genotype and makes 5.1 to $30.8 \%$ (Morgun et al., 2011).

The nucleolar activity is an important indicator of cell metabolic activity level (Haidarova, Kalashnik, 1999; Smolinski et al., 2007; Boulon et al., 2010; Stepinski, 2014). We revealed some differences in the activity of chromosome nucleolar organizer in seedling cells of the seeds from different Pinus pallasiana tree stands (Crimea, Donetsk and Krivoy Rog regions). For example, cells with up to 11 nucleoli were found in the seedlings of the natural population (Table 2).

We have found cells with the same number of nucleoli in the seed progeny of four tree plantations or with even higher number in some of them (Mariupol and Krivoy Rog plantations). There is a tendency towards decrease in the number of two-, three- and four-nucleolar cells in seedlings of the seeds from plantations (with the only exception for the one in Novoamvrosievka) in comparison to the control population. The percentage of cells with 3 to 7 nucleoli was $92.1 \%$ in the plant progenies of population, whereas the majority of seedling cells $(80.1$ to $85.4 \%)$ of the seeds from plantations had from 4 to 7 nucleoli. There were, on an average, 5.2 nucleoli in the seedling cells of the plant seeds from population and there were more (by 6.9 to $12.7 \%$ ) nucleoli in seed progenies from plantations.

The largest nuclei, nucleoli and the lowest nucleus-nucleolus ratios are characteristic of seedling cells of plant seeds from P. pallasiana population in Crimea (Table 3). The mean nuclear area of seed progeny from Crimean population was significantly (by 26.2\%) smaller only than that of the progenies of the Donetsk plantation. The nucleolar area of seed progeny from the above mentioned population was smaller only than that of the seedlings of the seeds from the same plantation (by 33.9\%) and of the seeds from the Krivoy Rog plantation (by $48.6 \%$ ). Nucleus-nucleolus ratios were higher in the seedlings of the seeds from planta- 
T a b le 2. The frequency of interphase nuclei with different number of nucleoli in seedling root cells of Pinus pallasiana D. Don from Crimean natural population and urban plantations in the steppe of Ukraine.

\begin{tabular}{|c|c|c|c|c|c|c|c|c|c|c|c|c|c|}
\hline \multirow{3}{*}{ Sample } & \multicolumn{12}{|c|}{ Frequency of nuclei with different nucleoli number, \% } & \multirow{3}{*}{$\begin{array}{l}\text { Mean number } \\
\text { of nucleoli } \\
\text { per nucleus }\end{array}$} \\
\hline & \multicolumn{12}{|c|}{ The number of nucleoli per nucleus } & \\
\hline & 1 & 2 & 3 & 4 & 5 & 6 & 7 & 8 & 9 & 10 & 11 & 12 & \\
\hline \multicolumn{14}{|c|}{ Crimean Mountains } \\
\hline $\begin{array}{l}\text { The population near } \\
\text { the settlement of Nikita }\end{array}$ & 0.3 & 2.3 & 10.7 & 18.9 & 23.6 & 28.1 & 10.8 & 3.3 & 1.6 & 0.3 & 0.1 & 0 & $5.20 \pm 0.05$ \\
\hline \multicolumn{14}{|c|}{ Donetsk region } \\
\hline $\begin{array}{l}\text { Novoamvrosievka } \\
\text { plantation }\end{array}$ & 0 & 0 & 5.6 & 19.8 & 23.8 & 27.5 & 14.3 & 6.3 & 2.0 & 0.5 & 0.2 & 0 & $5.56 \pm 0.05^{\star * *}$ \\
\hline Mariupol plantation & 0 & 1.8 & 6.1 & 11.2 & 24.1 & 29.6 & 15.2 & 6.7 & 4.4 & 0.5 & 0.3 & 0.1 & $5.74 \pm 0.05^{\star * *}$ \\
\hline Donetsk plantation & 0.3 & 1.77 & 4.5 & 13.9 & 22.1 & 26.0 & 18.2 & 8.8 & 2.9 & 1.3 & 0.16 & 0 & $5.86 \pm 0.05^{\star * *}$ \\
\hline \multicolumn{14}{|c|}{ Dnepropetrovsk region } \\
\hline Krivoy Rog plantation & 0 & 1.8 & 6.6 & 13.8 & 23.1 & 24.9 & 18.7 & 6.6 & 3.3 & 1.0 & 0.1 & 0.1 & $5.69 \pm 0.05^{* * *}$ \\
\hline
\end{tabular}

T a b le 3. Nucleus-nucleolus ratio in Pinus pallasiana D. Don seedlings from Crimean population and urban plantations in the steppe of Ukraine.

\begin{tabular}{|c|c|c|c|c|c|c|}
\hline \multirow[t]{2}{*}{ Sample } & \multicolumn{2}{|c|}{$\begin{array}{l}\text { Mean area of a nucleus } \\
\text { mkm }^{2}\end{array}$} & \multicolumn{2}{|c|}{$\begin{array}{l}\text { Mean area of the nucleoli } \\
\text { in a nucleus, } \mathrm{mkm}^{2}\end{array}$} & \multicolumn{2}{|c|}{ Nucleus-nucleolus ratio } \\
\hline & $\mathbf{M} \pm \mathbf{m}$ & $\mathrm{CV}, \%$ & $\mathbf{M} \pm \mathbf{m}$ & $\mathrm{CV}, \%$ & $\mathbf{M} \pm \mathbf{m}$ & $\mathrm{CV}, \%$ \\
\hline $\begin{array}{l}\text { The population near the } \\
\text { settlement of Nikita }\end{array}$ & $192.6 \pm 10.2$ & 37.5 & $28.62 \pm 1.4$ & 33.7 & $7.24 \pm 0.4$ & 42.1 \\
\hline $\begin{array}{l}\text { Novoamvrosievka } \\
\text { plantation }\end{array}$ & $167.2 \pm 5.8^{\star}$ & 45.0 & $26.05 \pm 1.7$ & 24.1 & $8.21 \pm 0.8$ & 65.1 \\
\hline $\begin{array}{l}\text { Mariupol } \\
\text { plantation }\end{array}$ & $188.6 \pm 8.8$ & 33.0 & $24.65 \pm 1.4^{*}$ & 39.7 & $8.59 \pm 0.6$ & 42.2 \\
\hline $\begin{array}{l}\text { Donetsk } \\
\text { plantation }\end{array}$ & $142.2 \pm 7.57^{\star \star \star}$ & 37.7 & $18.91 \pm 0.8^{* * *}$ & 35.7 & $7.73 \pm 0.3$ & 53.5 \\
\hline $\begin{array}{l}\text { Krivoy Rog } \\
\text { plantation }\end{array}$ & $192.1 \pm 7.8$ & 35.3 & $14.70 \pm 1.1^{\star * *}$ & 36.8 & $15.54 \pm 1.0^{\star * *}$ & 50.1 \\
\hline
\end{tabular}

tions in comparison with the plant progenies of the population by $6.8 \%$ (Donetsk), $13.4 \%$ (Novoamvrosievska), $18.6 \%$ (Mariupol) and $11.46 \%$ (Krivoy Rog). The increase in this ratio in seed progenies of plants exposed to technogenic emissions is associated with the smaller nuclear and nucleolar areas in seedling roots (Treré, 2000). A marked increase of the nucleusnucleolus ratio in seed progeny of plants growing in the iron ore dump is primarily predetermined by significantly smaller sizes of the nucleoli, than in control. Consequently, air and edaphic technogenic pollution increases the activity of chromosome nucleolar organizers in seed progenies of $P$. pallasiana.

In the course of laboratory studies of radon effects on Zebrina pendula Schirt., the nucleolar activity has turned out to be the most sensitive cytogenetic indicator (Butorina, 
Kalaev, 2000; Boulon et al., 2010). A high sensitivity of seed progeny of some conifer species to industrial pollution in the Southern Urals manifested itself through the higher rates of chromosomal disorders at the stages of anaphase and telophase of mitosis (Kalashnik, 2008). In the course of our studies, we have found chromosomal abnormalities to be the most sensitive cytogenetic indicator in the progeny of three Pinus pallasiana plantations, exposed to air pollutants, bridges clearly dominating among these abnormalities. Pathological mitosis and chromosomal abnormalities occurred with the same frequency in the progenies of plants growing in the ore-mining dump, lead and agglutination of chromosomes being predominant. This fact is indicative of the specific effects of edaphic and air pollution.

Though the frequency of chromosome aberrations in the cells of living organisms is widely used to evaluate the genotoxic effects of various physical and chemical agents on living organisms, the mechanisms of these mitosis anomalies' occurrence are poorly investigated so far (Harvey et al., 1997). All types of chromosomal aberrations are considered to be one phenomenon, as their common bases are the DNA one- and double strand breaks (Bryant, 1997). However, various types of chromosomal aberrations are caused by a different number of molecular genetic events involving various morphological regions of chromosomes, which significantly differ in their structural and functional characteristics. In addition, certain individual chromosomes within karyotype may differ significantly from each other in their participation rates in chromosomal aberrations (Richardson et al., 1998). Chromosomal aberrations are caused by some non-mutagenic chemicals, as well as metabolic poisons, which inhibit DNA synthesis and induce DNA double breaks. The occurrence of chromosomal aberrations depend on the specific genotype characteristics of an individual, controlling the functional activity of the proteins, which provide packing of primary DNA sequences (Morgan et al., 1998). Disintegration of the cell plasmatic membranes results in chromosomal aberrations. A low-intensity prolonged exposure to radiation causes a decrease in the membrane phospholipids' content; thus, changing its physical and chemical properties (viscosity and permeability), which in its turn violates the normal functioning of the cell, including its repair processes (Wojcik et al., 1996).

Cytogenetic abnormalities in seed progenies of woody plants in industrial regions result either from direct adverse effects of toxic air and soil pollutants, or from the accumulation of these pollutants, mutagens and heavy metals within the plant organs and their transfer to seed buds. On the other hand, higher frequencies of cytogenetic abnormalities in seed progenies may be caused by pathologic meiosis and seed bud fertilization with anomalous pollen. Pathologic meiosis associated with cytogenetic anomalies is observed in natural populations (Jeelani et al., 2013).

Thus, we have detected high frequency of cytogenetic abnormalities (pathologic mitosis, chromosomal aberrations and nucleolar organizer activity changes) in P. pallasiana seedlings of seeds from industrial regions of Ukrainian steppe (Donetsk and Krivoy Rog region). The highest rates of these abnormalities were characteristic of plant seed progenies from Krivoy Rog ore mining dumps and sites near Donetsk metallurgical enterprises where soil substrates and air is contaminated by heavy metals. Specific cytogenetic abnormalities in seed progenies are associated with dominating pollution type. 


\section{References}

Akinboro, A., Mohammed, K., Rathnasamy, S. \& Muniandy V.R. (2011). Genotoxicity assessment of water samples from the Sungai Dua River in Pulau Pinang, Malaysia, using the Allium cepa test. Tropical Life Sciences Research, 22(2), 23-35.

Belousov, M.V., Mashkina, O.S. \& Popov V.N. (2012). Cytogenetic response of Scots pine (Pinus sylvestris Linnaeus, 1753) (Pinaceae) to heavy metals. Comparative Cytogenetics, 6(1), 93-106. DOI: 10.3897/CompCytogen.v6i1.2017.

Bessonova, V. \& Grytsay Z. (2018). Content of plastid pigments in the needles of Pinus pallasiana D. Don in different forest growth conditions of anti-erosion planting. Ekológia (Bratislava), 37(4), 338-344. DOI: 10.2478/ eko-2018-0025.

Bochkov, N.P., Demin, N.V. \& Luchnik L.V. (1972). Classification and methods of registering of chromosome aberrations in somatic cells (in Russian). Genetika (Genetics), 8(5), 133-142.

Boulon, S., Westman, B.J., Hutten, S., Boisvert, F.M. \& Lamond A.I. (2010) The nucleolus under stress. Mol. Cell, 40, 216-227. DOI: 10.1016/j.molcel.2010.09.024.

Bryant, P.E. (1997). DNA damage, repair and chromosomal damage. Int. J. Radiat. Biol., 71, 675-680. DOI: $10.1080 / 095530097143680$.

Butorina, A.K. \& Kalaev V.N. (2000). Analysis of sensitivity of different criteria in cytogenetic monitoring. Russian Journal of Ecology, 31(3), 186. DOI: 10.1007/BF02762819.

Butorina, A.K., Kalaev, V.N., Mironov, A.N., Smorodinova, V.A., Mazurova, I.E., Doroshev, S.A. \& Senkevich E.V. (2001). Cytogenetic variation in populations of Scotch pine. Russian Journal of Ecology, 32(3), 198-202. DOI: 10.1023/A:1011366328809.

Butorina, A.K., Kalaev, V.N. \& Karpova S.S. (2002). Specific features in the course of the mitosis and nucleolar characteristics in seed progeny of drooping birch under the conditions of anthropogenic pollution. Cell and Tissue Biology, 44(4), 392-399.

Dovgalyuk, A.I., Kalinyak, T.B. \& Blume Ya.B. (2001). Cytogenetic effects of toxic metal salts on apical meristem cells of Allium cepa L. seedling roots. Cytology and Genetics, 35(2), 3-10.

Genisel, M., Turk, H., Erdal, S., Sisman, T., Demir, Y., Kohnehshahri, S.M. \& Kizilkaya M. (2015). Changes in inorganic composition and accumulation of heavy metals in aquatic plants growing in the areas contaminated by cement factory. Journal of Environmental Protection and Ecology, 16(4), 1297-1306.

Geras'kin, S.A., Vasilev, D.V., Dikarev, V.G., Udalova, A.A., Evseeva, T.I., Dikareva, N.S. \& Zimin V.L. (2005). Bioindication-based estimation of technogenic impact on Pinus sylvestris L. populations in the vicinity of a radioactive waste storage facility. Russian Journal of Ecology, 36(4), 249-258. DOI: 10.1007/s11184-005-0069-z.

Glińska, S., Bartczaka, M., Oleksiaka, S., Wolska, A., Gabara, B., Posmyk, M. \& Janas K. (2007). Effects of anthocyanin-rich extract from red cabbage leaves on meristematic cells of Allium cepa L. roots treated with heavy metals. Ecotoxicol. Environ. Saf., 68(3), 343-350. DOI: 10.1016/j.ecoenv.2007.02.004.

Haidarova, T.G. \& Kalashnik N.A. (1999). Nucleoli organizers as adaptive elements of conifer species. Cell and Tissue Biology, 41(12), 1086.

Harvey, A.N., Costa, N.D., Savage, J.R. \& Thacker J. (1997). Chromosomal aberrations induced by defined DNA doublestrand breaks: the origin of achromatic lesions. Somat. Cell. Mol. Genet., 23, 211-219.

Hozak, P., Roussel, P. \& Hernandez-Verdun D. (1992). Procedures for specific detection of silver-stained nucleolar proteins on western blots. J. Histochem. Cytochem., 40(8), 1089-1096. DOI: 10.1177/40.8.1619275.

Jeelani, S.M., Rani, S., Kumar, S., Kumari, S. \& Gupta R.C. (2013). Cytological studies of Brassicaceae Burn. (Cruciferae Juss.) from Western Himalayas. Cytology and Genetics, 47, 26-36. DOI: 10.3103/S0095452713010076.

Kalaev, V.N. \& Karpova S.S. (2003). The influence of air pollution on cytogenetic characteristics of birch seed progeny. Forest Genetics, 10, 11-18.

Kalashnik, N.A. (2008). Chromosome aberrations as indicator of technogenic impact on conifer stands. Russian Journal of Ecology, 39(4), 261-271. DOI: 10.1134/S106741360804005X.

Kalashnik, N.A. \& Yasovieva S.M. (2012). Analysis of meiotic chromosome aberrations in Siberian spruce (Picea obovata Ledeb.) under conditions of natural and technogenic stress. Russian Journal of Ecology, 43(6), 440-447. DOI: $10.1134 /$ S1067413612060057.

Koca, S., Turkoglu, S., Gencer, L. \& Ozdemir M. (2016). Research of genotoxic effect of olive mill wastewater with allium test system. Journal of Environmental Protection and Ecology, 17(2), 629-637.

Korshikov, I.I., Tkacheva, Y.A. \& Privalikhin S.N. (2012). Cytogenetic abnormalities in Norway spruce (Picea abies (L.) Karst.) seedlings from natural populations and an introduction plantation. Cytology and Genetics, 46(5), 280-284. DOI: 10.3103/S0095452712050064. 
Kumar, S.S., Singh, N.A., Kumar, V., Sunisha, B., Preeti, Sh., Deepali, S. \& Nath Sh.R. (2008). Impact of dust emission on plant vegetation in the vicinity of cement plant. Environmental Engineering and Management Journal, $7(1), 31-35$.

Liu, D., Wusheng, J. \& Deshen L. (1993). Effects of aluminium ion on root growth, cell division and nucleoli of garlic (Allium sativum L.). Environ. Pollut., 82, 295-299. DOI: 10.1016/0269-7491(93)90132-8.

Lysyi, A.E., Rhyzhenko, S.A., Kozyarin, I.P., Mel'nichenko, M.G. \& Kapnichuk V.G. (2007). Ecological, sanitary and hygienic problems and the ways to healthier environments in a large industrial region (in Russian). Kryvoy Rog.

Mishra, S., \& Siddiqui N.A. (2014). A review on environmental and health impacts of cement manufacturing emissions. International Journal of Geology, Agriculture and Environmental Science, 2(3), 26-31.

Morgan, W.F., Corcoran, J., Hartma, N.N., Kapian, M.I., Limoli, C.L. \& Ponnaiya B. (1998). DNA doublestrand breaks, chromosomal rearrangements, and genomic instability. Mutat Res., 404, 125-128.

Morgun, V.V., Larchenko, E.A., Kostyanovskiy, R.G. \& Katerynchuk A.M. (2011). The chiral mutagens: cytogenetic effects on higher plants. Cytology and Genetics, 45(4), 36-43. DOI: 10.3103/S0095452711040074.

Nouri, M. \& Haddioui A. (2016). Assessment of metals contamination and ecological risk in ait ammar abandoned iron mine soil, Morocco. Ekológia (Bratislava), 35(1), 32-49. DOI: 10.1515/eko-2016-0003.

Pausheva, Z.P. (1980). A practical course in plant cytology (in Russian). Moscow: Kolos.

Pekol, S., Baloğlu, M.C. \& Altunoğlu Ya.C. (2016). Evaluation of genotoxic and cytologic effects of environmental stress in wheat species with different ploidy levels. Turk. J. Biol., 40, 580-588. DOI: 10.3906/biy-1506-6.

Richardson, C., Moynahan, M.E. \& Jasin M. (1998). Doublestrand break repair by interchromosomal recombination: suppression of chromosomal translocations. Genesis Developments, 15, 3831-3842.

Shkarupa, V.M., Barilyak, I.R., Neumerzitskaya, L.V. \& Gumenyuk I.D. (2010). The gene-protective effect of sodium humate under conditions of induced oxidative stress. Cytology and Genetics, 44(1), 43-45. DOI: 10.3103/ S0095452710010081.

Smolinski, D.J., Niedojadlo, J., Noble, A. \& Gorska-Brylass A. (2007). Additional nucleoli and NOR activity during meiotic prophase I in larch (Larix decidua Mill.). Protoplasma, 232, 109-120. DOI: 10.1007/s00709-007-0270-y.

Stepinski, D. (2014). Functional ultrastructure of the plant nucleolus. Protoplasma, 251, 1285-1306. DOI: 10.1007/ s00709-014-0648-6.

Stevens, J.B., Liu, G., Bremer, S.W., Ye, K.J., Xu, W., Xu, J., Sun, G.S., Wu, S., Savasan, S., Krawetz, S.A., Ye, Ch.J. \& Heng H.H.Q. (2007). Mitotic cell death by chromosome fragmentation. Cancer Res., 67, 7686-7694. DOI: 10.1158/0008-5472.CAN-07-0472.

Trerè, D. (1994). Technical and methodological aspects of silver staining and measurement of nucleolar organizer region (NOR). Zentralblatt für Pathologie, 140, 11-14.

Trerè, D. (2000). AgNOR staining and quantification. Micron, 31(2), 127-131. DOI: 10.1016/S0968-4328(99)00069-4.

Wang, Q.L., Zhang, L.T., Zou, J.H., Liu, D.H. \& Yue J.Y. (2014). Effects of cadmium on root growth, cell division and micronuclei formation in root tip cells of Allium cepa var. agrogarum L. Fyton, 83, 291-298.

Wojcik, A., Bonk, K., Muller, W.U., Obe, G. \& Streffer C. (1996). Do DNA doublestrand breaks induced by Alu lead to development of novel aberrations in the second and third post treatment mitoses? Radiation Res., 145, 119-127. DOI: $10.2307 / 3579165$. 